\title{
Labyrinthe
}

14 | 2003

Constructions de la raison

\section{Grammaire et logique}

\section{Benjamin Spector}

\section{OpenEdition}

\section{Journals}

Édition électronique

URL : http://journals.openedition.org/labyrinthe/595

DOI : $10.4000 /$ labyrinthe.595

ISSN : 1950-6031

Éditeur

Hermann

Édition imprimée

Date de publication : 1 mai 2003

Pagination : 25-46

Référence électronique

Benjamin Spector, « Grammaire et logique », Labyrinthe [En ligne], 14 | 2003, mis en ligne le 11 avril 2005, consulté le 30 avril 2019. URL : http://journals.openedition.org/labyrinthe/595 ; DOI : 10.4000/ labyrinthe.595

Ce document a été généré automatiquement le 30 avril 2019

Propriété intellectuelle 


\title{
Grammaire et logique
}

\author{
Benjamin Spector
}

